\title{
An Action Research on Project-Based Learning and Understanding by Design and Their Effects on the Science Achievement and Attitude of Science Students
}

\author{
Prof. Richard Dean B. Rubrica, M. Ed \\ Faculty of University of Caloocan City, Philippines
}

\begin{abstract}
Project-Based Learning has been the leading strategy used by most of the top educational systems in the world. Authentic learning that addresses the $21^{\text {st }}$ century skills is what PBL offers. However, little research has been done to explore its potential in improving the quality of education in the country and what framework to be used to be able to "curricularize" PBL. The aim of this research is to examine the effect of Project-Based Learning using Understanding by Design framework in improving the academic achievement of grade 6 students in science 6. Two sections in the grade 6 level from Sta Quiteria Elementary School in Caloocan City was selected for the study. Group A (Gold) was taught through project-based learning technique and Group B (Garnet) was taught through a more traditional teaching technique. A pretest and posttest was administered on both groups to find out if there is a statistical difference between their achievements. There was a statistical difference between the mean academic achievement scores of pretest and posttest after the intervention. The statistical difference has proven the effectiveness of PBL as a more effective method in teaching science. In addition, motivation and attitude were positively impacted. Further studies and in-service trainings for teachers were recommended to discover the effectiveness of PBL in other subject areas.
\end{abstract}

Keywords: Project-Based Learning, Understanding by Design, Authentic Activities, Science teaching, $21^{\text {st }}$ century learning, Experiential Learning, Student Projects, Student Attitudes, Active Learning

DOI: $10.7176 / \mathrm{JEP} / 10-5-02$

\section{Introduction}

The Philippines educational system is on its progressive steps in completing the transition to the K-12 program. Science, being one of the core subjects in elementary education will again undergo a major program overhaul. Elementary science education in the country is evidently poor compare to its ASEAN neighbors. Student performance in the international studies (TIMMS 1995, 1999, 2003) is consistently low. The Philippines ranked $34^{\text {th }}$ out of 38 participating countries and the results from the National Achievement Test given by the Department of Education are also in dismaying figures (UNESCO, 2010).

The problem does not lay on the curriculum program per se, hence, everything boils down to the pedagogical roots. Students lose interest in learning science because its teaching is predominantly transmissive which makes it more abstract in the eyes of the students and therefore, seeing it as an irrelevant subject matter (UNESCO, 2010). Thus, as teachers, we have to provide organic experiences that will make the students construct knowledge meaningfully in an appropriate social context (Dewey, 1938). According to Lev Vygotsky's (1978) Zone of Proximal Development, children's inquisitiveness begins long before they attend formal schooling. For this reason, children are considered born scientists (Keller, 2012). Consequently, didactic pedagogy cannot cater their curiosity about the world and their questions about everything. Children learn science by doing science, by asking and exploring their answers to their questions (Martin, 2002). Science is not a subject to be taught, but rather a process for learning something new (Keller, 2012). Scientific knowledge is shared through social transactions and interactions between the learners (Roth 1990). Learning entails active efforts of the learner and therefore, learning science is an active process (Tyler 1949).

Despite the radical changes in the curriculum the Department of Education is making through the years to improve the quality of education, teachers are still widely using didactic pedagogy and generic lesson plans in delivering their lessons. The K-12 program is anchoring the philosophy of educational constructivism that requires authentic pedagogical approach and has to reflect the real-world interconnections in science through authentic assessments (Tam, 2000). Constructivism is also a learning strategy that draws students' prior knowledge and skills to be able to synthesize new understanding (Matthews, 2003). Knowledge learned at the level of rote memory rarely transfers; transfer occurs when the learner knows and understand the concepts and be able to apply it to solve problems in different situation. Learning with understanding is more likely to promote transfer than just memorizing a text (Wiggins \& McTighe, 2001). Students at this point in time live in a world with vast sources of information. Therefore, as teachers we have to teach the them how to properly choose and use that information (Trilling \& Fadel, 2009). There is also a need to prepare them in the rapidly changing world of work. Collaboration, critical thinking, problem solving, and self-management are the success skills we need to equip our students (Larmer \& Mergendoller, 2015).In that sense, we as teachers should embrace our new role as 
learning coach and manager (Barron \& Darling-Hammond, 2008).

I am a science teacher for about five years since I entered the public school. Sta. Quiteria elementary school is one of the seven schools in the district of Tanque in Caloocan City. I teach six sections of sixth grade science. There are a total of thirteen sections in the grade six and I am teaching almost half of it. We have one homogeneous section that we consider the 'cream' section which makes the remaining sections heterogeneous. Students are required to take a diagnostic test at the beginning of the school year to assess the content that has to be taught with greater emphasis and to have data to be compared in the achievement test at the end of year following the spiral approach of the K-12 program. The results of the diagnostic exam served as my basis in choosing my subjects in the action research. I took the two sections at the bottom of the list which happens to be two of my classes. They got the lowest mean scores which I think will be a great venue to test the effectiveness of Project-Based Learning method. Section Gold is made up of 21 boys and 23 girls. All 44 students have low SES and 11 are beneficiaries of Pantawid Pamilyang Pilipino Program or 4P's, a government program that grants conditional allowances for the indigent families within the school community to be able to send their children to school. Section Garnet is made up of 25 boys and 21 girls. The same as section Gold, all 46 students have low SES and 9 of them are beneficiaries of 4P's. Indigence is a common problem surrounding public education. Some of my students even have to earn money for themselves to be able to go to school which greatly affects their capability to learn.

Throughout my years being a science teacher I observed that students lacked motivation and drive to become successful in Science. Everytime I try to engage my students to discussion what I only get are blank stares. Sometimes I ask myself if what I am doing is still worthwhile in the eyes of my students. Students consistently struggle to grasp science concepts because of the stigma attached to the subject. Students think that what they will do in science is just a bunch of memorization activities and seemed to believe that success in the class would be too difficult. Disengagement was noticeable compared to other subjects such as Araling Panlipunan and MAPEH. This action research was developed around my concern for my students in science. I am highly concerned about their academic growth, attitude, and motivation towards science that revolves around their critical thinking skills. As I observe, the longer the time I stay in front of the classroom the lesser they learn and the more I let them explore, the more they ask questions hence, the more they understand. Moreover, science teachers are most of the time focused on teaching the content and not learning the content.

There is no one-size-fits-all strategy or approach to address these issues. The need to hone the $21^{\text {s }}$ itury society that can keep up with the rapid technological advancements and globalization has brought us to the point of rethinking our educational system that has been caught in a web of educational views originated centuries ago (Barron \& Darling-Hammond, 2008). We need an innovative educational approach that will address our nation's educational dilemma. Rooted in the progressive education movement of William Heard Kilpatrick and John Dewey, Project-Based Learning or PBL is an approach where students try to find solutions to an essential question that is based on a real world challenge. This approach requires students to actively investigate and explore significant content and learn skills that are crucial to the process of inquiry to be able to answer the essential question that will result to deeper learning through active exploration of real-world problems and challenges (Condliffe, 2016; Iwamoto et al., 2016; Harmer \& Strokes, 2014; Holmes, 2012; Bell, 2010; Thomas, 2000; Katz \& Chard, 1992). According to Bell, (2010) Project-Based Learning is the basis of the curriculum and not just a supplementary activity to support learning. To be able to "curricularize" PBL, it needs to have a curriculum design that suites its core principles (Thomas, 2000). Understanding by Design or UbD by Wiggins and McTighe, (2004) is a three-step curriculum framework that takes a means-ends approach or "backwards" in designing and implementing a curriculum. Understanding by Design starts with the end goal- the desired results and identifies the necessary assessment evidences before thinking of the instructional procedures (Wiggins \& McTighe, 2004). In this study, I want to discover the over all impact of PBL in UbD framework in my students' achievement in science as well as their motivation and behavior in the classroom.

\section{PBL: Project-Based Learning}

Project-Based Learning (PBL) is a model for classroom activity that is a lot different from the usual teachercentered classroom practices. Project-Based Learning activities are long-term, interdisciplinary, student-centered and integrated with real-world issues and problem solving. This method fosters abstract tasks to explore and solve complex issues (Condliffe, 2016; Iwamoto et al., 2016; Harmer \& Strokes, 2014; Harmer \& Strokes, 2014; Holmes, 2012; Bell, 2010; Thomas, 2000; Katz \& Chard, 1992; ). It promotes understanding of the underlying concepts rather than just practicing rote memory skills. Project-Based Learning approach uses projects as vehicles to encourage student motivation and to provide means for demonstrating and explaining what they have learned. In PBL, the students explore, make judgments, interpret, and synthesize information in meaningful and creative ways. Project-Based Learning is a good resort in honing the $21^{\text {st }}$ century skills of the students (Educational Technology Division, Malaysia, 2006). Ravitz, Hixson, English, \& Mergendoller (2012) defined $21^{\text {st }}$ Century skills as: productivity and accountability, social and cross-cultural skills, creativity and innovation, 
critical thinking and problem solving, communication and collaboration, information, communication and technology literacy, flexibility and adaptability, initiative and self-direction, and leadership and responsibility. Project-Based learning promotes learning that results from the demonstration of performance where the students are going to use the knowledge and skills they acquired. According to Harmer and Strokes, (2014) PBL has key features which give its distinction; learning by doing, role of the facilitator, interdisciplinary, collaboration on the group work, and an end product. The genesis of PBL is inquiry where children pursue knowledge by asking questions that triggered their natural curiosity (Bell, 2010).

Recent studies are emphasizing the benefits of PBL; increased academic achievement, increased application and retention of information, critical thinking, communication, and collaboration (Condliffe, 2016; Iwamoto et al., 2016; Harmer \& Strokes, 2014; Holmes, 2012; Bell, 2010; Thomas, 2000; Katz \& Chard, 1992;), but what is and what is not a PBL project? Project is common tradition across the different subject areas. However, there are certain criteria that has to be present in a project to be considered PBL. Thomas (2000) on his article "A Review of Research on Project-Based Learning" states the five criteria of a PBL project. Project-Based Learning projects are central and not peripheral to the curriculum, projects are focused on questions or problems that 'drive' students to encounter the central concept of the curriculum of a discipline, projects involve students in a constructive investigation, projects are student-driven to some significant degree, and projects are realistic and not school-like. After Thomas (2000) created his comprehensive review of the Project-Based Learning approach, his work became the most cited article on PBL researches. After a decade, Bell, (2010) made another comprehensive review on PBL. According to Bell, (2010) PBL is an innovative teaching approach that addresses a multitude of skills critical for the success in the $21^{\text {st }}$ century. Bell (2010) argues in his review that students need to be more responsible for their own learning and the teachers should embrace their new role as guide-on-theside and not as sage-on-stage. Harmer and Strokes, (2014) made a review on the benefits and challenges of Project-Based Learning. The main advantages of PBL according to Harmer and Strokes, (2014) include: claims of improved academic results, the development of wider skills, increased student motivation and enjoyment, students learn through revision, enhanced outreach and engagement beyond academia and advantages for lecturer. Harmer and Strokes, (2014) also outlined some of the predominant challenges of the Project-Based Learning raised in the literature. Some of the significant identified challenges across the discipline are that of group work, preference for traditional teaching styles, assessment, and weight of work not only for students but also for teachers and administrators. Proper planning and scaffolding are some of the ways cited by Harmer and Strokes, (2014) in order to avoid these challenges. Another comprehensive review of Project-Based Learning by Condliffe, (2016) focused on the PBL approaches in the K-12 settings, core PBL design principles and implications for the field, and PBL implementation research. Moreover, Condliffe, (2016) discussed how students develop new skills and knowledge in PBL K-12 classrooms; PBL promotes construction of knowledge, cultivates student engagement, use scaffolds to guide student learning, encourage student choice, and support collaborative learning. Students are expected to demonstrate their learning by creating a product that answers the essential question, provide opportunities for student reflection and teacher feedback and present product to authentic public audiences.

The Buck Institute for Education or (BIE) is a non-profit organization dedicated in helping teachers use PBL effectively in their classrooms. Buck Institute for Education created the "Gold Standard PBL" because of the growing popularity of PBL many teachers and schools may jump on the PBL bandwagon. Without clear guidance and adequate preparation, curricular problems will crop up. Poorly designed and implemented PBL will frustrate students, disappoint teachers, and damage PBL's reputation. The "Gold Standard PBL" has the Essential Project Design Elements that has the key knowledge, understanding and success skills at the center as desired goals. Around the key knowledge, understanding and success skills are; design and plan, align to standards, build the culture, manage the culture, manage the activities, scaffold student learning, assess student learning and engage and coach. Design and plan is where teachers create or adapt a project for their context and students, and plan implementation from launch to culmination while allowing for some degree of student voice and choice. Aligning to standards is where teachers use standards to plan the project and make sure it addresses the key knowledge and understanding from subject areas. Building the culture explicitly and implicitly promote student independence and growth, inquiry, team spirit, and attention to quality. Managing activities to teach teachers and students to organize tasks, schedules, and use resources properly. Scaffolding student learning uses formative and summative assessments of knowledge, understanding, and success skills which include self and peer assessments. Engaging and coaching give students sense of direction, encouragement, and celebration. 


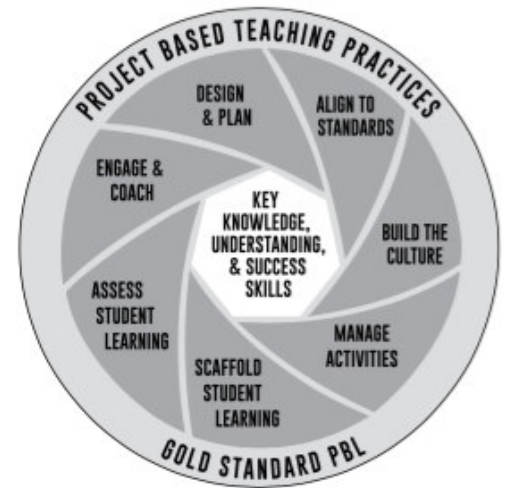

Figure 1. BIE Gold Standard PBL Essential Project Design Elements

The Educational Technology Division, Malaysia, (2006) states the six steps in formulating a Project-Based Learning program. The first step is giving the 'essential question' or the 'driving question'. This is a real-world topic that will engage the students to begin an in-depth investigation. The teacher has to make sure that the questions are based on the situations that are authentic and relevant to the students. The second step is designing a plan project. In designing a project plan the teacher has to consider the content standards to be addressed and involve the students in the planning process. In that way the project shall maintain its centrality to the curriculum. The third step is creating a schedule. Provide a timeline for the components of the projects. Give the students reasonable amount of time to come up with a meaningful project. The fourth step is monitoring the students and project progress. The teacher should inculcate the value of collaboration and communication among the members of the group. Always check the progress of the project by checking their copy of the schedule of project. The fourth step is assessing the outcome of the project. Diagnostic feedback is essential in assessing the work of the students. It gives the students design their projects more effectively. The sixth and the last step is evaluating the experience. Use rubrics in evaluating the outputs of the students to measure the authenticity and meaningfulness of the project. Make the students reflect after the evaluation period. Make the students share their experiences in making the projects and on how they can improve as a team.

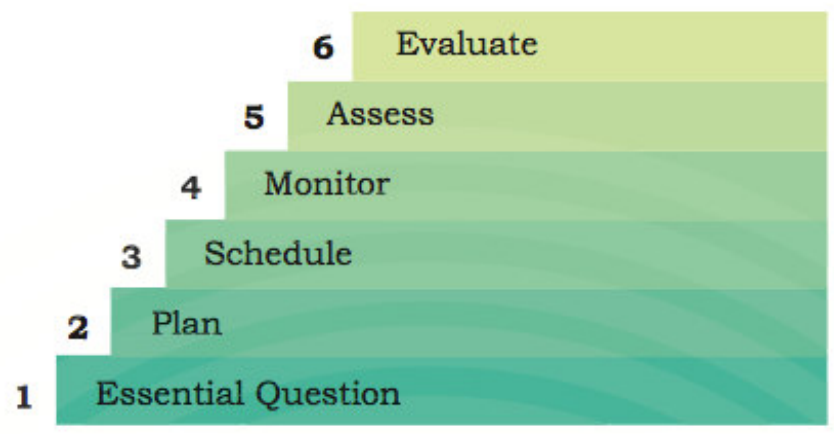

Figure 2. Steps in PBL

\section{Review of the Research on Project-Based Learning}

When considering to implement the action research it is important to confirm previous research regarding the effect of Project-Based Learning in increasing student achievement and improving student motivation and attitudes to help me guide my own research. This analysis informed and guided my efforts to implement a treatment in my class. Research has proven that through PBL, students become better problem solvers, researchers, and critical thinkers (Bell, 2010; Thomas, 2000; Condliffe, 2016). Students who may struggle in a traditional instructional setting have often been found to do well when they work in a PBL class (Bell, 2010; Thomas, 2000; Condliffe, 2016). The effectiveness of PBL has been investigated in various studies (Condliffe, 2016; Iwamoto et al., 2016; Chiang \& Lee, 2016; Mayer, 2016; Cervantea, et al., 2015; Khaliq, et al., 2015; Harmer \& Strokes, 2014; Redmond, 2014; Holmes, 2012; Bell, 2010; Yancin, et al., 2009; Thomas, 2000; Katz \& Chard, 1992;) in different subject areas as well as deepening students' transfer skills. Research has proven that through PBL, students become a better problem-solvers, researchers, and critical thinkers (Thomas, 2000, Bell, 2010, Harmer and Strokes, (2014), Condliffe, 2016). Students in PBL not only learn real-world application of knowledge and skills but also analytic skill (Katz \& Chard, 1992). Most of the literature on Project-Based Learning are in the K-12 setting which strongly suggest the effectiveness of the model in the K-12 program in the country. 
Researches on the effect of project-based learning are positive on both the achievement and affective domain. In a study conducted by ( Halvorsen, Brugar, Block, Strachan, Berka, and Brown, 2014), two sets of teachers 2 from from the high SES and 4 from the low SES and a subset of their students participated to find out if there is significant difference between the two groups in terms of their academic achievement in social studies and content literacy. The researchers used two project based learning units on the states standards in economics, civic and government. The researchers used a formative experiment approach and the data were both quantitative and quantitative. The participants came from two different school districts. The results of the study revealed that the students who came from a low SES scored statistically the same as the students who came form a high SES. The teachers who applied the project-based program became more concern on the 'understanding' of the students of the concepts.

Another study on the effects of project-based learning in increasing academic achievement was conducted by Hernandez-Ramoz and De La Paz (2009). A total of 70 students participated in the study from a District of Northern Califonia. The students were divided into a control group and the experimental group. A technology assisted project-based approach will be given to the experimental group in a six-week history unit on early $19^{\text {th }}$ century U. S. History. The researchers examined the content knowledge tests, group projects, and attitudes and opinions survey to determine the relative benefits of the program to the students. The results of the program revealed a significant gains of students in the PBL compare with the control group who underwent a more traditional teaching and learning program. The students' work in the intervention also revealed growth in their historical thinking skills and they were able to grasp the fundamental understanding that history is more than presenting and memorizing facts.

Cakici and Turkmen (2013) made a study on the effect of project-based approach on children's achievement and attitude in science in a primary school in the Northwestern part of Turkey. The study consisted of 44 fifth grade students that was divided into the control group and experimental group who underwent the intervention using the project-based learning strategies. The researchers used a pretest posttest control group of quasiexperimental research design. During the application of the project-based learning approach, the researcher carefully observed all students on how they crafted their projects. The researchers gave the students some scaffolding on the project by giving some clues and by encouraging them to be more creative in making their projects. The results of the study show a significant difference in terms of achievement in science as a result of making learning more enjoyable and meaningful. However, there was no significant differences on the attitude towards science. The researchers inferred that the reason are the difficulties the students experienced during the project making activities. Project-based learning is relatively new to the students and scaffolding and gradual implantation of the approach are some of the recommendations given by the researchers.

A study conducted by Khaliq, Alam, and Mushtaq (2015) investigated the effectiveness of project-based learning for teaching science at elementary level. One of the federal government high schools was randomly selected as a sample school. Then one section of grade 8 class was randomly selected to participate in the study. A chapter about the 'Environment' was taught through project-based learning. A pretest and a posttest in the subject of science was developed to evaluate the academic achievement of the students before and after the completion of the experiment. Consequently, the results showed that the students who underwent the treatment performed better than the control group. Project-based learning technique was found to be more effective teaching approach in teaching science because it elicits the natural inquisitiveness of the students to explore. A project calendar was given together with the rubric to maintain the focus of the students in accomplishing the proposed project. Khaliq, et al., (2015) recommended to use PBL in classrooms particularly in science subjects.

A study conducted by Yalcin, Turgut, and Buyukasap, (2009) aimed to discover the effect of Project-Based learning on Science Undergraduates' learning of electricity, attitude towards physics and scientific process skills. The total 90 undergraduates (prospected teachers) in the Science Teacher Training Department in Bayburt education faculty in Turkey was used in the study. A set of pretest and posttest was administered to the experimental and control group to discover if there is a statistical difference in their achievement and attitudes towards physics and science process skills. The results show that there were statistical differences between experimental and control group with respect to students' attitudes and the results also proved that project-based learning enhanced the learning of the students through authentic teaching and learning process.

Cervantes, B., Hemmer L. \& Kauzekanani K. (2015) investigated the impact of project-based learning on the achievement of the students in mathematics and in reading. Cerventez, et al. 2015, performed a causalcomparative study to compare the achievement of grade seven and grade eight students on two schools in a district in south Texas US of the school year 2011-2012. The researchers used experimental and control groups where PBL was used as teaching method for the experimental group and traditional approach was used in the control group. The State of Texas Assessments of Academic Readiness (STARR) was the tool used for the outcome of the learning program. The result of the study shows that students who underwent the PBL program scored significantly higher in the STARR than the control group who was taught using the more traditional method of teaching. 
A study conducted by Redmond, K. (2014) reports that project-based learning improves the academic achievement of the students through collaboration, active participation, and meaningful projects. The primary focus of the research is academic achievement which resulted in data collection surrounding the research question, "How does project-based learning impact student achievement?". Redmond, (2014) used two sections of fourth grade science. Each section underwent a treatment phase and non-treatment phase. The score that was used in the statistical analysis were generated from the Northwest Evaluation Association Measures of Academic Progress NWEA MAP test. The results of the statistical analysis revealed that after the treatment phase the students scored in the test significantly higher than the non-treatment phase.

The researcher also used variety of collection methods to help her solidify her data analysis. Aside from the pretest and posttest the researcher also conducted a survey which measured the motivation level of the student. Interview, class journals and a computer application which is Class Dojo were used to determine the attitude of the students towards the treatment phase of the study. The students were highly motivated during the span of the treatment because of the collaborative exercises given by the researcher. The researcher also noticed according to her class journals that some of her problem students were highly engaged during the span of the study which made her conclude that project-based learning really works on different types of students. In the interview, the students told the researcher that before they find science as a very boring subject but because of the engaging projects and activities during the treatment the students are now having a positive outlook on the subject that gave them intrinsic motivation to study science. With the help of Class Dojo, the researcher easily tracked and scored students' attitudes during the span of the treatment. In just a click in her device she was able to score the specific attitude of the students during the activity whether it is a positive or a negative attitude. The data out of it helped her solidify the data from the post tests which tells that project based learning can increase student achievement.

The data from Redmond, (2014) is very helpful in identifying the key on how teachers can intensify projectbased learning in the classroom. According to Redmond (2014) it is imperative for the teachers to build the plan and implement project-based learning at the beginning of the school year and make it as another classroom routine where the students know how to participate in. In that way the process of collaboration and research will become spontaneous to the students.

Project-Based learning method has proven its effectiveness not only in increasing academic achievement but also the $21^{\text {st }}$ century skills of the students as reported in the research of Holmes (2012) about the effects of the project-based learning on $21^{\text {st }}$ century skills and no left behind policy accountability standards. Holmes, (2012) focused on the effectiveness of PBL through the lenses of the $21^{\text {st }}$ century skills. The researcher wanted to prove that PBL is an effective teaching method across the different subject areas even with the initial conflict which he wanted to prove. Holmes, (2012) saw the conflict in the NCLB accountability standards by which students may not be able to perform PBL projects and activities by which will require $21^{\text {st }}$ century skills such as computer literacy, creativity, communication, and collaboration. Collaboration is an integral part of the PBL model (Cervantes, et al., 2015) where students communicate and share ideas and concepts about the topic. Holmes, (2012) tested PBL on the students' reading achievement, technology literacy, and $21^{\text {st }}$ century skills. Students who participated in the Digital Biographies PBL unit demonstrated an increase in reading achievement. However, according to the statistical analysis of the mean scores of the comparison group and the experimental group are not statistically different. Although, according to Holmes (2012), this is due to the very small sample size which was the most crucial part of the limitations of the research. Students in the special group had an increase in achievement in the Florida Comprehensive Assessment Test. The overall FCAT probability rates of the study group increased from 81.73 to 84.33 during the study period. In the technology literacy, the students demonstrated and increase in technology literacy skills after the Digital Biographies PBL unit. Constructing and Demonstrating Knowledge was the first indicator approaching significance. The students' ability to carry out variety of tasks is what the indicator evaluated. The overall score for the ST2L was also approaching significance with p-value of .055 that indicates that PBL is an effective method to increase technology skills and literacy of the students (Holmes, 2012). Moreover, the study group who underwent the PBL unit had a greater increase in constructing and demonstrating knowledge compared to the comparison group. The data shows the technology achievement gap between the study group and the comparison group after the implementation of the digital bibliographies PBL unit. In addition, the study group demonstrated better in the $21^{\text {st }}$ century skills such as in learning and innovation and communication compare with the comparison group using the five-point scale rubric. With all the data presented by the researcher, Project-Based Learning shows promise as a way to help students meet the challenges of developing $21^{\text {st }}$ century skills.

Iwamoto, et al., (2006) argued that Project-Based Learning method as an alternative pedagogical approach is effective in increasing the academic achievement of the students. The key indicators for higher academic performance were high self-efficacy, high level of perceived control, and growth mindset. Iwamoto, et al. (2006) believe that lecture-centered teaching methods lacked necessary tools needed to meet the demands to today's employment needs. In order to address the issue, Iwamoto et al. (2006) utilized an active-learning strategy 
intervention called standards-focused project-based learning (PBL). The main objective of the research is to measure the effectiveness of the alternative teaching approach based on constructivist ideas to address the low student achievement and engagement of the students in the undergraduate level psychology course and to know what are the changes that can be brought about by engaging the psychology students in PBL. The researchers used two sets of freshmen and sophomore psychology students as subjects. Using a one-way analysis of variance (ANOVA) to determine if there is a statistical difference between the mean scores of the control and experimental group. The results revealed that with a confidence interval of $95 \%$ the ANOVA was significant, $\mathrm{F}(3,97)=12.912, \mathrm{p}<.01$. Iwamoto, et al. (2006) also found out that students in the experimental group appeared engaged in the process and actively discussed the topics within their respective group. The researchers had one challenge that was observed in both experimental groups and that is students had a very difficult time starting their projects. The students experienced confusion and uncertainty and they requested examples and wanted more specific directions about the project.

Project-Based Learning is not just effective in increasing the academic achievement of the students but also improving students' attitude and motivation towards learning (Altun Yancin, et al., 2009; Chiang \& Lee, 2016; Erdem, 2012; Altun Yancin, et al. (2009) investigated the effect of project based learning on the first year science undergraduates' attitudes towards physics, electricity achievement, and the development of scientific process skills. The participants were 90 first year science undergraduate students from Science Teacher Training Department in Bayburt Education Faculty in Turkey. Pre tests and post tests were given to both experimental and control group. The unit about electricity was taught using the project based learning approach to the experimental group while a more traditional teacher-centered approach was used in the control group. It was found that the achievement scores in the unit about electricity of the experimental group was statistically significantly higher than the control group. It was also found that the scores of the experimental group with respect to their scientific process skills and attitude were higher than the control group. The researchers interviewed five students from the experimental group and asked things that served as reasons for them to score higher in the post test. The results of the interview revealed that students gained confidence in their own learning and initiative to discover knowledge and skills needed to accomplish the project with the help of the driving question at the beginning of the unit. Difficulties such as time on task, division of labor and finding funds for the project were common among the interviewees because project based learning approach was new to them.

Chiang, C. L. \& Lee, H. (2016) investigated the effect of project-based learning method on the motivation and problem-solving ability of the vocational high school students in eastern Taiwan. There were 46 students in the treatment group and 42 students in the control group majored in food and beverages. The treatment group were given project-based teaching method and control group students were given traditional method during the four-week period. The researchers used quasi-experiment and qualitative methods to investigate whether or not students who participated in the project-based learning improved their motivation and problem-solving abilities. Questionnaires consist of learning motivations scales and problem solving ability were given in both groups. Results showed that both the students' learning motivation and problem solving abilities were positively affected by the project-based learning method. Mayer, (2016) investigated the the students' perceptions of life skill development in project-based learning schools. The results show that students' perception on time management, collaboration, communication, and self-directedness drastically improved. The study revealed that the students' perception of their life skills improved through the implementation of Project-Based Learning approach.

\section{Understanding by Design (UbD)}

Understanding by Design (UbD) is the brainchild of Grant Wiggins and Jay McTighe (2005). Teaching is a means to an end three-step curriculum framework. The framework gathers learning outcome and assessment evidences before crafting instructional procedures. Wiggins \& McTighe (2005) defined backward design as an approach where teachers identify what are the evidences they want to reach before they plan what they teach and how. Understanding by Design lessons contribute to the lasting and meaningful learning of the students because the goal of UbD is understanding, that is the ability to "Transfer" the knowledge and skills learned into different context or situation Wiggins \& McTighe (2005).

A process to designing curriculum by beginning with the end in mind and designing toward that end. In backward design, one starts with the end - the desired results (goals or standards) - and identifies the evidence necessary to determine that the results have been achieved, that is, the assessments. With the results and assessments clearly specified, one can determine the necessary (enabling) knowledge and skill, and the teaching needed to equip students to perform. (Wiggins \& McTighe, 2005, p. 290). The three stages of the Understanding by Design process to create a unit plan. This figure illustrates the overall process used to develop curriculum following the UbD format. Adapted from Wiggins and McTighe, p. 18. "Curriculum should lay out the most effective ways of achieving specific results" (Wiggins and McTighe, 2005, p.14). Understanding by design can be broken into three stages. 


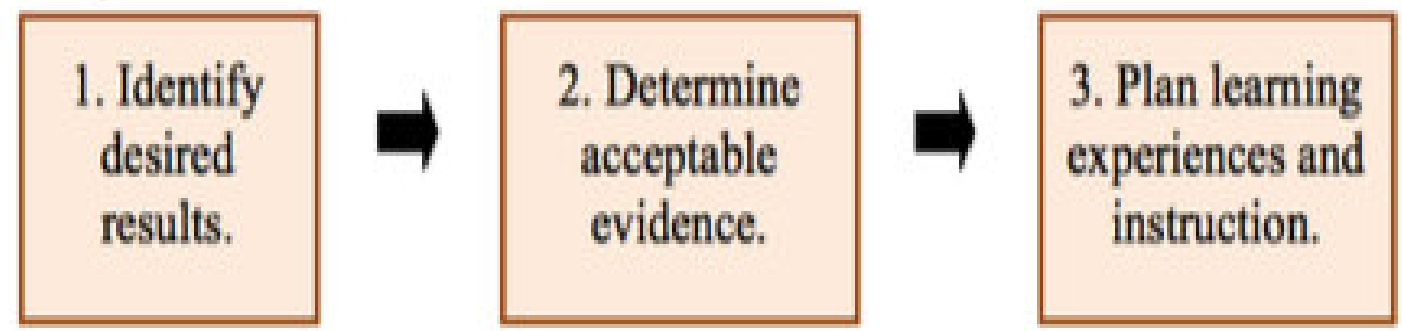

Figure 3. UbD Stages (Wiggins and McTighe, 2005, p.18)

Understanding by Design suggests that educators should focus on what specific learning needs to occur first before putting any thought into the activities they want to implement (Wiggins and McTighe, 2011). Understanding as an educational aim will result in high-level achievement for it will provide more opportunities for the students to apply their learning in meaningful authentic contexts. The students will therefore, be able to transfer what they have learned- that is the ability to apply understandings, knowledge, and skills effectively in new situations (Wiggins and McTighe, 2005). Wiggins \& McTighe, (2005) identify the twin sins of common curricular design; the activity focused teaching and the coverage focused teaching. The activity focused teaching provides students with tantamount of "hands-on but minds-off" activities which is prevalent in the elementary grade students while the coverage focused on the other hand is prevalent in the high school and college levels. Understanding by Design is a framework not an educational program and according to (Wiggins and McTighe, 2011, p. 3) in their book "The Understanding by Design Guide to Creating High-Quality Units" UbD is based on eight key tenets:

1. UbD is a way of thinking purposefully about curricular planning, not a rigid program or prescriptive recipe.

2. A primary goal of UbD is developing and deepening student under- standing - the ability to make meaning of learning via "big ideas" and to transfer learning.

3. UbD unpacks and transforms content standards and mission-related goals into relevant Stage 1 elements and appropriate assessments in Stage 2.

4. Understanding is revealed when students autonomously make sense of and transfer their learning through authentic performance. Six facets of understanding-the capacities to explain, interpret, apply, shift perspective, empathize, and self-assess - serve as indicators of understanding.

5. Effective curriculum is planned "backward" from long-term desired results through a three-stage design process (Desired Results, Evidence, Learning Plan). This process helps to avoid the twin problems of "textbook coverage" and "activity- oriented teaching" in which no clear priorities and purposes are apparent.

6. Teachers are coaches of understanding, not mere purveyors of content or activity. They focus on ensuring learning, not just teaching (and assuming that what was taught was learned); they always aim — and checkfor successful meaning- making and transfer by the learner.

7. Regular reviews of units and curriculum against design standards enhance curricular quality and effectiveness.

8. UbD reflects a continuous-improvement approach to achievement. The results of our designs-student performance - inform needed adjustments in curriculum as well as instruction; we must stop, analyze, and adjust as needed, on a regular basis.

Teaching for the purpose understanding is not simply another way of teaching, just as manageable as usual lecture-exercise-test method. It involves genuinely more intricate classrooms. Understanding has six facets (Wiggins \& McTighe, 2011), which are:

1. Explanation: A mutual declaration of the meaning of words spoken, actions, motives, and providing thorough and justifiable accounts of phenomena, facts, and data.

2. Interpretation: An explanation of the meaning of another's artistic or creative work; an elucidation through telling meaningful stories, offer apt translations, provide a revealing historical or personal or accessible through images, anecdotes, analogies, and models.

3. Applying: To make an application or to effectively use and adapt what they know in diverse contexts.

4. Have Perspective: The state of having a meaningful interrelationship: See and hear points of view through critical eyes and ears; see the big picture.

5. Empathizing: Find value in what others might find odd, alien, or implausible; perceive on the basis or prior indirect experience or related to someone else's emotional experience.

6. Have Self-knowledge: Perceive the personal style, prejudices, projections, and habits of the mind that both shape and impedes our own understanding; they are aware of what they do not understand and why understanding is so hard.

Wiggins and McTighe, (2005) emphasize that Understanding by Design is a framework and not a prescriptive program. Moreover, it is a design that has understanding as the goal. Understanding by Design is also not a philosophy of education, nor does it require a belief in any pedagogical system or approach, it rather 
provide a guidance on how to undertake any pedagogical system or approach. Understanding by Design also focused on the design of curricular units as opposed to individual lesson plans or broader programs but with broader context of program of courses this is because individual lessons are too short to allow for in-depth development of big ideas, exploration of essential questions, and authentic application. However, lesson plans should logically flow from unit plans and lessons will be more purposeful and connected when informed $b$ a larger unit and course design (Wiggins \& McTighe, 2005). The overarching elements of UbD are- Essential question, Enduring Understandings, Key Performance Tasks, and Rubrics. According to Wiggins and McTighe, (2005), for a question to be considered essential it should mean to; cause genuine and relevant inquiry into the big and core content; provoke deep thought, lively discussion, sustained inquiry, and new understandings as well as more questions; require students to consider alternatives, weigh evidences, support their ideas, and justify their answers; stimulate vital, ongoing rethinking of big ideas, assumptions, prior lessons; spark meaningful connection with prior learning and personal experiences; and naturally recur, creating opportunities for "Transfer" to other situations and subjects.

Table 1. The Logic of Backward Design

\begin{tabular}{|l|l|l|}
\hline \multicolumn{1}{|c|}{ Stage 1 } & \multicolumn{1}{c|}{ Stage 2 } & \multicolumn{1}{c|}{ Stage 3 } \\
\hline $\begin{array}{l}\text { If the desired end result is for } \\
\text { learners to... -.-> }\end{array}$ & $\begin{array}{l}\text { Then you need evidence of the } \\
\text { learners' ability... - } \rightarrow\end{array}$ & $\begin{array}{l}\text { then the learning events need } \\
\text { to... }\end{array}$ \\
\hline $\begin{array}{l}\text { Drive in heavy traffic aggressive } \\
\text { and inattentive drivers without } \\
\text { accident or anger. }\end{array}$ & $\begin{array}{l}\text { Handle real as well as simulated } \\
\text { driving conditions in which } \\
\text { defensive driving is required by } \\
\text { traffic and behavior of other } \\
\text { drivers. }\end{array}$ & $\begin{array}{l}\text { Help novices become skilled in } \\
\text { handling the automobile, help } \\
\text { them learn and practice } \\
\text { defensive driving in variety of } \\
\text { situations; help them learn to } \\
\text { defuse anger using humor and } \\
\text { different thought patterns, etc. }\end{array}$ \\
\hline
\end{tabular}

Table 2. Wiggins, Grant and J. Mc Tighe. (1998). Understanding by Design Unit Template, Association for Supervision and Curriculum Development

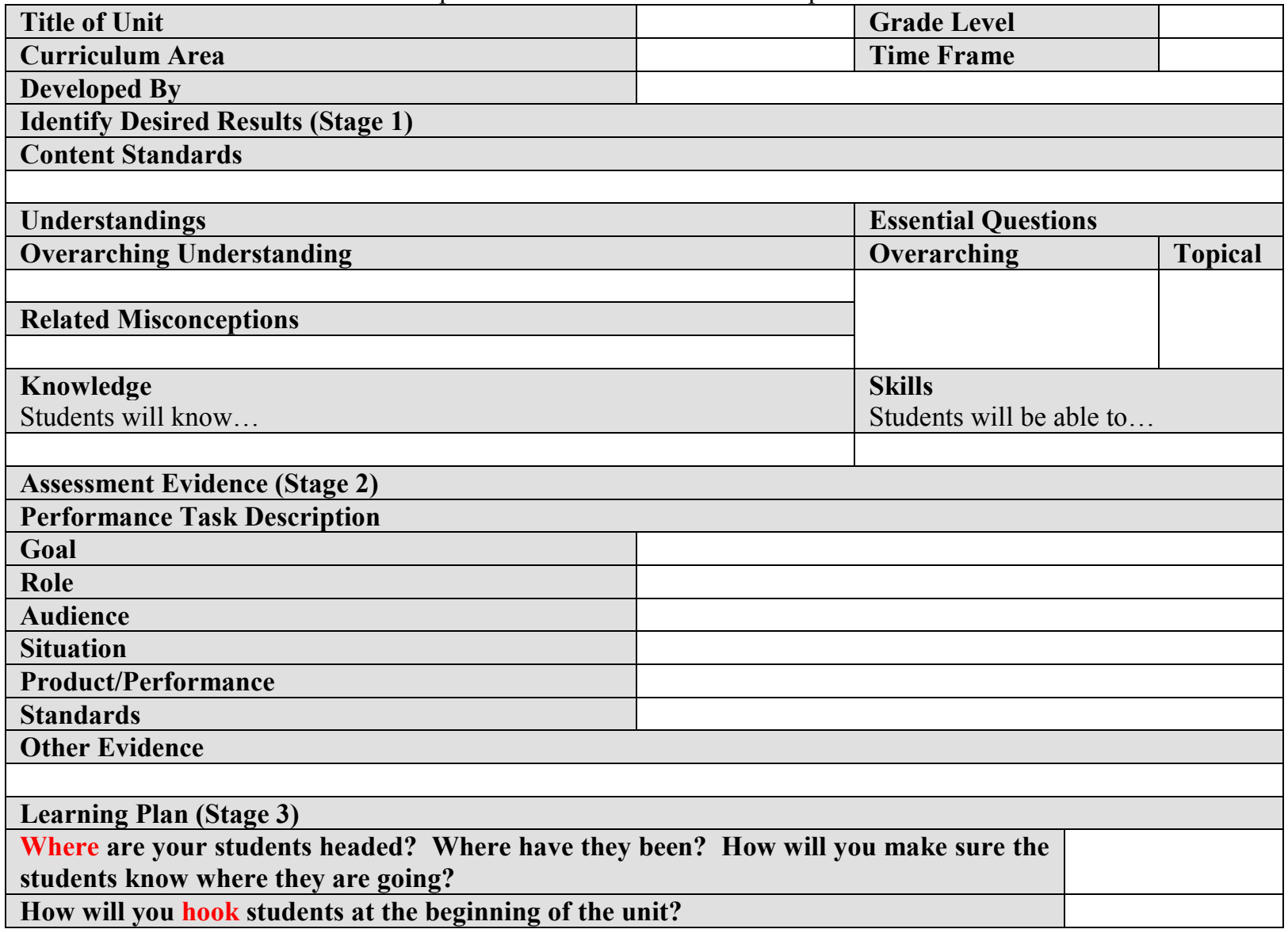


What events will help students experience and explore the big idea and questions in the unit? How will you equip them with needed skills and knowledge?

How will you cause students to reflect and rethink? How will you guide them in rehearsing, revising, and refining their work?

How will you help students to exhibit and self-evaluate their growing skills, knowledge, and understanding throughout the unit?

How will you tailor and otherwise personalize the learning plan to optimize the engagement and effectiveness of ALL students, without compromising the goals of the unit?

How will you organize and sequence the learning activities to optimize the engagement and achievement of ALL students?

\section{Review of the Research on Understanding by Design (UbD)}

Research provide a clear evidence that UbD based lesson units increase student achievement across subject areas (Sgro \& Freeman, 2008; Anwaruddin, 2013; Schiller, 2015; Hodaeian \& Biria, 2015; Tumlos-Castillo, 2015; Yurtseven \& Altun, 2015; Almasaeid, 2017;). Most of the researches available discuss EFL, Science, Student motivation and attitudes, and Writing learning modules.

Tumlos-Castillo, (2015) conducted a study to find out the effectiveness of Understanding by Design (UbD) in writing learning modules. The researcher wanted to find out if the teachers have eventually grasped the key principles of the UbD framework since its introduction in 2010. Using questionnaire that ask how helpful the design framework in systematically preparing the learning modules. The Understanding by Design framework has helped enhance the delivery of instruction through new curricular developments such as curriculum mapping, construction of unit assessment matrices, revision of the learning module components, more integration of values in lesson, more effective management of instructional time, and enriched student learnings.

The effect of Understanding by Design in EFL teachers' perceptions was investigated by Anwarudin, (2013). The participants of the study consisted of 21 EFL teachers in University College of Dhaka. The researcher facilitated 3 professional workshops for in-service EFL teachers. A series of observation, questionnaire, and interviews was used to assess the teacher participants. Findings show that the teachers in UC believed that they can greatly benefit from using UbD in their context. None of them expressed any doubt on the UbD's effectiveness in outcome-based education. In the interview, most of the participants believe that adopting UbD will greatly help students to learn easily. Moreover, Yurtseven \& Altun, (2015) investigated the effect of UbD in EFL teaching and learning motivation and views. The researchers used a mixed method, pretest and posttest was administered for the quantitative data and survey questionnaire and interviews for the qualitative data. Result show that students' motivation increased drastically and the students' view in learning English as foreign language became more positive which had made the teaching process easier. Reading comprehension and focus attitudes of the EFL learners was investigated by Hodaeian \& Biria, (2015). Results show that the use of $\mathrm{UbD}$ increased the reading comprehension level and positive attitudes of the students.

Schiller, (2015) used UbD in designing unit lesson plans for the next generation science standards in the topic of evolution with the correlation to the NGSS performance expectations. Findings show that UbD unit lessons increased the achievement of the students in the unit of evolution using the NGSS assessment. In addition, students showed interest in learning science content. Recently, the impact of Understanding by Design in increasing the achievement of the students in science was also investigated by Almasaeid, (2017). Sixty $8^{\text {th }}$ grade students from Al Majd Model School for boys and Al Abdaa Model School for girls in Dubai was used as subjects for the study. Pre test using the Academic Achievement of Science Test (AAST) for $8^{\text {th }}$ grade before applying the UbD model was given for the validity and reliability of the study tools. The students were divided into experimental and control group. The experimental group was taught using the UbD framed lessons while the control group was taught using the current method used in science classes. After the post test the results show that there is a statistical difference between the mean scores of the pre test and post test of the experimental and the control groups. Almasaeid, (2017) argued that the best way to improve science pedagogy is to use Understanding by Design as framework. In addition, critical thinking is one of the success skills students need to thrive and Sgro \& Freeman, (2008) in their study asserted that Understanding by Design is a framework that can be used to teach the students critical thinking.

\section{Understanding Project-Based Learning by Design}

The diversity of defining features coupled with the lack of a universally accepted model or theory of ProjectBased Learning has resulted in a great variety of PBL research and development activities (Thomas, 2000; Condliffe, 2016;). In his review of literature, Thomas, (2000) indicated that there is no universally accepted set of practices constituted PBL, nor was there an agreed-upon distinction between PBL and other student-centered, inquiry based approach. In addition to that, Condliffe, (2016) in her rigorous review on PBL argues that there 
still no agreement on whether PBL design principles should address the content of learning. Project-Based Learning and other inquiry-based student-centered approached endured resistance and criticism from educators and administrators who believe in the importance of students developing scientific content knowledge in traditional subject areas (Condliffe, 2016). PBL now-a-days become increasingly popular around the world because it emphasizes deeper learning and success skills.

Project-Based Learning (PBL) and Understanding by Design (UbD) both revolve around an "Essential Question", established goals are formal, long term goals, such as state standards, district program goals, departmental objectives, and exit level outcomes. It stimulates thought, to provoke inquiry and to spark more questions not just pat answers. Deep and transferable understandings depend upon framing around the essential questions (Wiggins \& McTighe, 2005; Bell, 2010; Thomas, 2000; Condliffe, 2016). Essential questions have to go to the heart of the problem or topic to be able to expand the normal repertoire to make sure to put the learners in charge of their learning (Wiggins \& McTighe, 2005; Bell, 2010; Thomas, 2000; Condliffe, 2016). Well designed projects can spark enthusiasm to students, leading to increased class participation. Research conclude that for students to develop high-order thinking skills, they have to take part in complex, meaningful projects that require sustained engagement, collaboration, research, management of resources, and the development of a performance and product that require them to apply their knowledge and skills to solve real-world problems (Condliffe, 2016).

Questions in implementing PBL revolve around the curriculum, students, teachers, instruction, and assessment hold back PBL's full potential in making a compete paradigm shift of the educational arena. The following questions were adapted from McTighe, (2016).

Curriculum: How will we teach academic, discipline-based standards through a project-based curriculum? How will we plan projects-within and across the grades- to insure a coherent learning experience for students? How will we systematically develop the understandings, skills and habits of the mind that will students need to succeed with PBL? How will we avoid "project overload" for students, parents, and teachers?

Students: What understandings, skills and habits of mind will students need to be able to effectively succeed with PBL?

Teachers: What skills will teachers need to effectively facilitate PBL? What professional developments and on-going support will staff need for PBL?

Instruction: In what ways will instruction need to change as we move to PBL?

Assessment: How will we develop a coherent assessment system aligned to our mission and academic outcomes? What observable indicators will show achievement of desired learner outcomes in the short term and in the long run? How will we assess growth in the $21^{\text {st }}$ century skills and habits of mind needed for the successful project work? Although there are still tantamount of follow-up questions to be considered, addressing these primary concerns is integral in the success of PBL. Understanding by Design has three stages: Stage 1 Desired results; Stage 2 Assessment evidences; Stage 3 Teaching and learning process. In integrating the PBL approach, the Desired results will focus on teaching for understanding while developing self directed $21^{\text {st }}$ century skills (e.g., 4Cs-critical thinking, collaboration, creativity, communication using the "big ideas" so that students can transfer their learning to new situations. Projects are generally interdisciplinary in nature, but may be applied in a specific subject area. Knowledge and skills are seen as the "means to larger ends". The assessment evidences are obtained through authentic products and performances developed in conjunction with the projects. Requires high-order thinking and transfer applications. Multiple rubrics are used to assess the various facets of the project. Evaluation may be done by authentic audiences and may be more personalized. Student self-assessment is emphasized. In the teaching and learning process, teachers serve primarily as facilitators of the "meaning making" of the students in doing their project work. Some direct instruction and modeling is provided as needed. On-going assessment and project monitoring is needed. This is what Understanding by Design PBL approach look like (McTighe, 2016). 
Table 3. UbD-PBL Unit Plan Template

Identify Desired Results (Stage 1)

Content Standards

Goal (s):

What student outcomes do we seek as a result of this project:

- $\quad$ disciplinary outcomes? - transdisciplinary outcomes?

\begin{tabular}{|c|c|c|c|}
\hline \multirow{2}{*}{\multicolumn{2}{|c|}{$\begin{array}{l}\text { Understandings } \\
\text { Overarching Understanding }\end{array}$}} & \multicolumn{2}{|l|}{ Essential Questions } \\
\hline & & Overarching & \multirow{3}{*}{$\begin{array}{l}\text { Topical } \\
\text {-What essential } \\
\text { questions will guide } \\
\text { the project? }\end{array}$} \\
\hline $\begin{array}{l}\text { What understandings } \\
\text { outcomes to be realized? }\end{array}$ & students need for these & $\begin{array}{l}\text {-What essential questions } \\
\text { will support the } \\
\text { development of desired } \\
\text { understandings? }\end{array}$ & \\
\hline \multicolumn{2}{|l|}{ Related Misconceptions } & & \\
\hline \multirow{2}{*}{\multicolumn{2}{|c|}{$\begin{array}{l}\text { Knowledge } \\
\text { Students will know... } \\
\text { What knowledge and skills will students need to } \\
\text { successfully complete the project? }\end{array}$}} & \multicolumn{2}{|l|}{$\begin{array}{l}\text { Skills } \\
\text { Students will be able to... }\end{array}$} \\
\hline & & & \\
\hline \multicolumn{4}{|c|}{ Assessment Evidence (Stage 2) } \\
\hline \multicolumn{4}{|c|}{ Performance Task Description } \\
\hline Goal & \multirow{6}{*}{\multicolumn{3}{|c|}{$\begin{array}{l}\text { Evaluative Criteria: } \\
\text { - How will students demonstrate their learning for this project? } \\
\text { - By what criteria (success indicators) will student performances and/or products } \\
\text { be evaluated? }\end{array}$}} \\
\hline Role & & & \\
\hline Audience & & & \\
\hline Situation & & & \\
\hline Product/Performance & & & \\
\hline Standards & & & \\
\hline \multicolumn{4}{|l|}{ Other Evidence } \\
\hline \multicolumn{4}{|c|}{$\begin{array}{l}\text { Supplementary Evidence: What other assessment evidences will we collect (e.g., to assess skills and } \\
\text { knowledge)? }\end{array}$} \\
\hline \multicolumn{4}{|c|}{ Learning Plan (Stage 3) } \\
\hline $\begin{array}{l}\text {-What instruction will be } \\
\text {-What differentiated instr }\end{array}$ & $\begin{array}{l}\text { led to develop the needed ur } \\
\text { n may be needed to support }\end{array}$ & $\begin{array}{l}\text { lerstandings, knowledge an } \\
\text { ll students? }\end{array}$ & ills? \\
\hline
\end{tabular}

\section{General statement of the problem}

This action research revolves around my deep concern about the students' achievement in science, motivation, behavior in the classroom and their overall academic growth. I want to give my students an opportunity to learn in a way that could change their point of view on learning. The main purpose of this study is to discover the effects of Project-Based Learning approach using Understanding by Design framework in the achievement of grade 6 students in Sta. Quiteria Elementary school in science. In this section I will discuss the treatment that was implemented, the class demographics, the instrumentation that was used in the action research, the process of data collection and analysis techniques, and how the purpose of this study was achieved. This study is of crucial importance as it investigates what contributions the implementation of Project-Based Learning had on students' achievement in Science and the effectiveness of Understanding by Design as framework for PBL approach.

\section{Specific questions}

In this action research I asked the following questions:

1. Is there a difference in the science achievement between Group A and Group B before the treatment?

2. Is there a difference in the science achievement between Group A and Group B after the treatment?

3. What is the overall effect of the intervention?

\section{Subjects}

The results of the diagnostic test were integral in choosing the participants in this study. Section Garnet and Gold were at the bottom of the list of the diagnostic test administered which I deemed important in seeing the overall effects of PBL using the UbD framework in increasing student achievement in science. Section Gold is made up of 21 boys and 23 girls. All 44 students have low SES and 11 are beneficiaries of the Pantawid Pamilyang Pilipino Program or 4P's, a government program that grantsconditional allowances for the indigent families 
within the school community to be able to send their children to school. Section Garnet is made up of 25 boys and 21 girls. The same as section Gold, all 46 students have low SES and 9 of them are beneficiaries of 4P's. The participants were divided into two groups where section Gold (Group A) and section Garnet (Group B).

\section{Setting}

The participants were $6^{\text {th }}$ grade students from Sta. Quiteria Elementary school in Caloocan city. The Schools Division of Caloocan is composed of seven districts with 54 elementary schools and 33 high schools. Sta. Quiteria elementary school is a member of the Tanque district in south Caloocan with seven schools. Among the seven schools, Sta. Quiteria Elementary school is second in terms of population with 3,712 students and 95 teachers with permanent item for the school year 2017-2018.

\section{Instruments and data gathering procedure}

I used the Action Research model to answer my research questions and also to gain better understanding of my own professional practice. Action Research is a research methodology designed to have subjects, in particular teachers, to investigate an element of a particular activity with the aim of determining whether the changes can produce effective and positive improvement, especially student learning. Action research is process through which teachers apply a scholarly paradigm which results for continuous advancement in the teaching and learning process while also gaining a deeper understanding of educational situations and context. (Young, M., Rapp, E., \& Murphy, J., 2010).

Action research is considered an iterative or cyclical process involving multiple cycles. The major steps of planning, action, observation, and reflection are the first cycle moves which are then used to revise the process in the next process (Young, et al. 2010). The iterative action research cycle begins with the teacher researcher identifying the problem and deciding on the focus of the inquiry and creating a (Plan). The (Action) are the activities implemented in the classroom which are then recorded and (Observed) by the teacher researcher. The data collected will then critically, individually and collaboratively reflected upon that will lead to (Revising) the plan to create some more effective classroom activities (Young, M., Rapp, E., \& Murphy, J., 2010).

The K-12 second quarter units on Parts and Functions of the Human Body Systems and Animals was designed to be taught in conjunction with the more traditional curriculum. Project-Based Learning in Understanding by Design framework was used in teaching section Gold (Group A) the units on body systems and animal. Section Garnet (Group B) on the other hand was taught using a more traditional didactic teaching which focuses on lecturing and rote memory skills. At the beginning of each unit, the teacher gave the students the "Driving Problem/Question" which was the kick-off of the project.

The teacher gave the students the templates of the project proposal which they will submit after two weeks. The idea is to give the students time to acquire information which will give them some idea on how they are going to formulate their proposals. The students are given the freedom to create whatever project they can come up so solve the driving problem/question. The students are asked to research whatever they think will help them build their proposed project. The students are guided with their "Project Design Student Learning Guide" and the "Project Rubric" that the teacher gave them before the submission of their project proposal. In that way, the students will know already what are the competencies they need to acquire on the entire quarter and for the project to be bounded by the learning outcomes in the guide. Moreover, for the students to know what are the things they have to improve in their project and the things they have to eliminate. The rubric will also give them the glimpse on how the teacher will grade them at the end of the project making process (Wolf and Stevens, 2007). The body systems unit was a four-week unit while the unit on animals was a two-week unit. The curriculum plan together with the essential questions are shown in (table 4). 
Table 4. Action Plan with Essential Questions

\section{Quarter: 2 Domain: Living things and Their Environment}

\section{Unit: I Parts and Function}

Essential Question: How can I make my loved ones who have heart, lung, brain, stomach, muscle, skin, and bone ailments feel better?

\section{Human Body System}

Learning Competency:

Explain how the organs of each organ system work together S6LT-IIa-b-1

\begin{tabular}{|c|c|c|c|c|c|}
\hline & Day 1 & Day 2 & Day 3 & Day 4 & Day 5 \\
\hline Week 1 & $\begin{array}{lr}\text { Identify } & \text { and } \\
\text { describe } & \text { the } \\
\text { functions of the } \\
\text { organs } \\
\text { Musculo-Skeletal } \\
\text { System }\end{array}$ & $\begin{array}{l}\text { Describe how the } \\
\text { organs of } \\
\text { Musculo-Skeletal } \\
\text { System work } \\
\text { together }\end{array}$ & $\begin{array}{l}\text { - Identify } \\
\text { and describe the } \\
\text { functions of the } \\
\text { organs of } \\
\text { Integumentary } \\
\text { System } \\
\text { - Describ } \\
\text { e how the organs } \\
\text { of } \\
\text { Integumentary } \\
\text { System work } \\
\text { together }\end{array}$ & $\begin{array}{l}\text { - Identify } \\
\text { and describe the } \\
\text { functions of the } \\
\text { organs of } \\
\text { Digestive System } \\
\text { Describe } \\
\text { how the organs of } \\
\text { Digestive System } \\
\text { work together }\end{array}$ & $\begin{array}{l}\text { SUMMATIV } \\
\text { E TEST }\end{array}$ \\
\hline Week 2 & $\begin{array}{l}\text { - Identify } \\
\text { and describe the } \\
\text { functions of the } \\
\text { organs } \\
\text { Respiratory } \\
\text { System } \\
\text { - Describe } \\
\text { how the organs } \\
\text { of Respiratory } \\
\text { System work } \\
\text { together }\end{array}$ & $\begin{array}{l}\text { - Identify } \\
\text { and describe the } \\
\text { functions of the } \\
\text { organs } \\
\text { Circulatory } \\
\text { System } \\
\text { - Describe } \\
\text { how the organs of } \\
\text { Circulatory } \\
\text { System work } \\
\text { together }\end{array}$ & $\begin{array}{l}\text { Identify and } \\
\text { describe the } \\
\text { functions of the } \\
\text { organs } \\
\text { Nervous System }\end{array}$ & $\begin{array}{l}\text { Describe how the } \\
\text { organs of Nervous } \\
\text { System work } \\
\text { together }\end{array}$ & $\begin{array}{l}\text { SUMMATIV } \\
\text { E TEST }\end{array}$ \\
\hline \multicolumn{6}{|c|}{$\begin{array}{l}\text { Learning Competency: } \\
\text { Explain how the different organ systems work together } \boldsymbol{S 6 L T - I I c - d - 2}\end{array}$} \\
\hline Week 3 & \multicolumn{2}{|c|}{$\begin{array}{l}\text { Describe how Musculo-skeletal and } \\
\text { Integumentary System work together }\end{array}$} & \multicolumn{2}{|c|}{$\begin{array}{l}\text { Describe how the organs of the } \\
\text { Digestive, Respiratory and Circulatory } \\
\text { Systems work together }\end{array}$} & $\begin{array}{l}\text { SUMMATIV } \\
\text { E TEST }\end{array}$ \\
\hline Week 4 & $\begin{array}{l}\text { Describe how the } \\
\text { nervous and } \\
\text { integumentary } \\
\text { systems work } \\
\text { together }\end{array}$ & $\begin{array}{l}\text { Describe how the } \\
\text { nervous system } \\
\text { controls all the } \\
\text { organ systems of } \\
\text { the body }\end{array}$ & $\begin{array}{l}\text { Discuss } \\
\text { healthful habits } \\
\text { that promote } \\
\text { proper } \\
\text { functioning of } \\
\text { all the organs } \\
\text { systems in the } \\
\text { body }\end{array}$ & $\begin{array}{l}\text { Make a chart } \\
\text { showing healthful } \\
\text { habits that } \\
\text { promote proper } \\
\text { functioning of all } \\
\text { the organs systems } \\
\text { in the body }\end{array}$ & $\begin{array}{l}\text { SUMMATIV } \\
\text { E TEST }\end{array}$ \\
\hline \multicolumn{6}{|c|}{$\begin{array}{l}\text { Unit II Animals } \\
\text { Essential Question: Since we re living in an urban area, how can we make a self-sustaining source of food/ } \\
\text { income using our knowledge in animals, plants and ecosystem? } \\
\text { Learning Competency: Determine the Distinguishing Characteristics of Vertebrates and Invertebrates } \boldsymbol{S 6 M T -} \\
\text { IIe-f-3 }\end{array}$} \\
\hline Week 5 & $\begin{array}{l}\text { Describe the } \\
\text { characteristics of } \\
\text { vertebrates and } \\
\text { invertebrates. }\end{array}$ & $\begin{array}{l}\text { Describe the } \\
\text { characteristics of } \\
\text { mammals and } \\
\text { birds }\end{array}$ & $\begin{array}{l}\text { Describe the } \\
\text { characteristics of } \\
\text { reptiles, } \\
\text { amphibians, and } \\
\text { fishes }\end{array}$ & $\begin{array}{l}\text { Classify vertebrates } \\
\text { birds, reptiles, a } \\
\text { fishes }\end{array}$ & $\begin{array}{l}\text { into mammals, } \\
\text { mphibians, and }\end{array}$ \\
\hline
\end{tabular}




\begin{tabular}{|c|c|c|c|c|}
\hline Week 6 & $\begin{array}{l}\text { Describe the } \\
\text { characteristics of } \\
\text { the following } \\
\text { groups of } \\
\text { invertebrates: } \\
\text {-insects and } \\
\text { spiders } \\
\text { - Localize } \\
\text { the terms } \\
\text { depending on the } \\
\text { available } \\
\text { resources }\end{array}$ & $\begin{array}{l}\text { Describe the } \\
\text { characteristics of } \\
\text { the following } \\
\text { groups of } \\
\text { invertebrates: } \\
\text {-worms, shellfish } \\
\text { and snail }\end{array}$ & $\begin{array}{l}\text { Classify invertebrates into insects, } \\
\text { spiders, worms, shellfish and snail }\end{array}$ & $\begin{array}{l}\text { Make an } \\
\text { inventory of } \\
\text { vertebrates and } \\
\text { invertebrates } \\
\text { that are } \\
\text { commonly seen } \\
\text { in the } \\
\text { community } \\
\text { Practice ways } \\
\text { of caring and } \\
\text { protecting } \\
\text { these animals }\end{array}$ \\
\hline
\end{tabular}

To answer the research questions and to better understand the overall impact of Project-Based Learning using Understanding by Design framework, I collected and analyzed both quantitative and qualitative data. I used the mixed method to be able to triangulate the data to have multiple viewpoints which increased the credibility and validity of the results (Yeasmin \& Rahman, 2012). According to Mertens \& Hesse-Biber (2012), data both quantitative and qualitative can be mixed in illustrating a more complete understanding of the phenomenon being studied. The triangulating data collection method includes pre test and post test, Student survey questionnaire, teacher journal, student interview and Class Dojo software program. Quantitative analysis using SPSS were used to analyze the test scores and the survey data. Qualitative analysis methods used were coding and identification of emergent themes. I utilized the triangulation process in my study as means of achieving greater validity of my research data.The diagnostic test served as the pre test to identify the participants in the study and the data also served as means in identifying whether the the groups are of the same level of intelligence in science. The second quarterly exam served as the post test that gauged the effectiveness of the treatment on Group A. The student survey is a Likert scale questionnaire adapted from the study of (Redmond, 2014) on the effects of project-based learning on students' achievement on a fourth grade classroom. The survey was administered on both groups after UbD-PBL units to track students' opinions of science class and motivation towards science learning. The survey also has open-ended questions to allow me a better understanding of their views. Given that Group A and Group B had the lowest achievement in the diagnostic test, I allowed them to answer the open-ended questions using Filipino. In that way, they were able to genuinely express themselves on what they feel towards my science class. Student interviews were also conducted in small groups in Group A to see their perspectives about the unit projects. My journal helped me record observations, analyze experiences, and reflect on my practice and other things happening in the classroom. Class Dojo a software application was used as a data collection tool to collect positive and negative behaviors of the students during science class. Students are awarded positive points when they exhibit excellence in the classroom and negative points for behaviors not conductive to a learning environment. Class Dojo can also connect to their parents and view students progress in school in terms of class participation and activities. However, in the context of the parents of public school students most of them are incapable using such technology and have a very little time connecting to the web. In this study, Class Dojo was used mainly to help me record and reward student positive behavior in science class. Class Dojo was used consistently on both groups throughout the quarter to be able to observe behavioral patterns between the groups (see Figures 4 and 5).

Figure 4. Class Dojo positive responses points

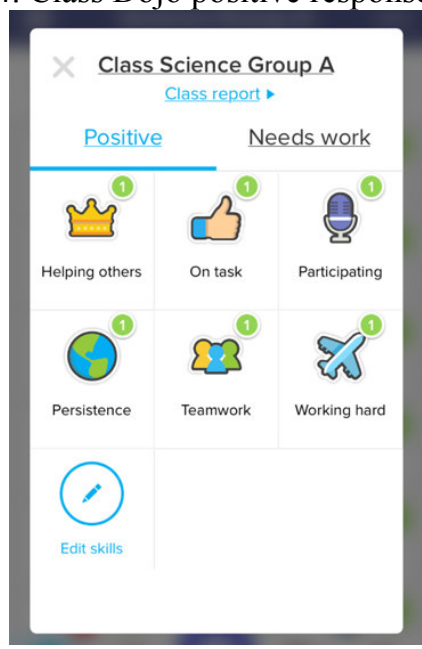


Figure 5. Class Dojo negative responses points

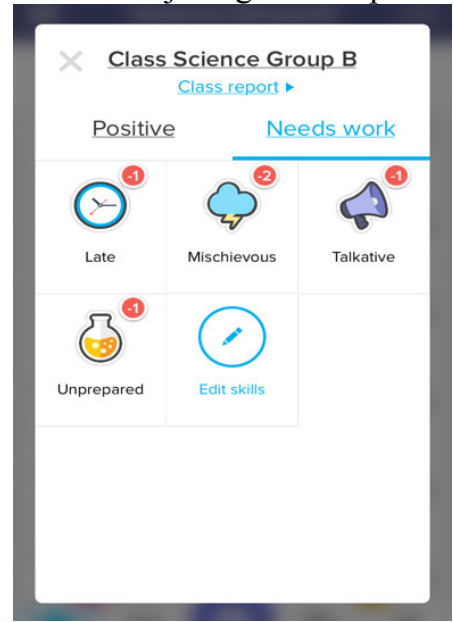

\section{Discussion, Conclusion and Recommendations}

In this section, data both quantitative and qualitative were rigorously examined. The data that I have collected in this study adheres to action research methodology. The data allowed me to visualize differences between the two groups and provided insight to the research questions that allowed me to draw conclusions from this action research.

\section{Discussion of Results}

\section{Student Achievement}

The focal point of this action research is to find out the impact of Project-Based Learning method using Understanding by Design as its framework on student achievement in the science classroom. Two groups having the same achievement in the diagnostic examination at the beginning of the school year participated in the study. To determine whether or not the scores of the groups are the same and to answer the first and second research questions, the scores were calculated using the IBM SPSS (version 24) software package. Upon the initial glance, Group A (Gold) and Group B (Garnet) have an almost identical mean (see Table 5). Looking at the standard deviation, Group A has a more spread out scores with 5.469 compare with 3.725 of Group B. The standard deviation of the two groups are statistically different according to Levene's test for equality of variance with a $p$ value of .000 which is less than .05. I used the independent samples $t$-test to determine if there is a statistical difference between the mean scores of the two groups in the diagnostic test (see Table 6). In Table 6 we can see that the $p$ value in the sig. column is .860 which is greater than .05 which means that the mean scores of the two groups are not statistically significantly different.

Table 5. Diagnostic Test Mean Scores

\begin{tabular}{|ll|c|c|c|c|}
\hline \multicolumn{5}{|c|}{ Group Statistics } \\
& Section & $\mathrm{N}$ & Mean & $\begin{array}{c}\text { Std. } \\
\text { Deviation }\end{array}$ & $\begin{array}{c}\text { Std. Error } \\
\text { Mean }\end{array}$ \\
\hline Diagnostic & Gold & 44 & 17.52 & 5.496 & .829 \\
\cline { 2 - 7 } & Garnet & 46 & 17.35 & 3.725 & .549 \\
\hline
\end{tabular}

Table 6. Independent Samples T-Test of Diagnostic Test Results Independent Samples Test

\begin{tabular}{|c|c|c|c|c|c|c|c|c|c|c|}
\hline \multicolumn{11}{|c|}{ Independent Samples Test } \\
\hline & & \multicolumn{2}{|c|}{$\begin{array}{l}\text { Levene's Test for } \\
\text { Equality of Variances }\end{array}$} & \multicolumn{7}{|c|}{ t-test for Equality of Means } \\
\hline & & \multirow[b]{2}{*}{$\mathrm{F}$} & \multirow[b]{2}{*}{ Sig. } & \multirow[b]{2}{*}{$\mathrm{t}$} & \multirow[b]{2}{*}{ df } & \multirow{2}{*}{$\begin{array}{l}\text { Sig. (2- } \\
\text { tailed) }\end{array}$} & \multirow{2}{*}{$\begin{array}{c}\text { Mean } \\
\text { Difference }\end{array}$} & \multirow{2}{*}{$\begin{array}{l}\text { Std. Error } \\
\text { Difference }\end{array}$} & \multicolumn{2}{|c|}{$\begin{array}{l}95 \% \text { Confidence } \\
\text { Interval of the } \\
\text { Difference }\end{array}$} \\
\hline & & & & & & & & & Lower & Upper \\
\hline \multirow[t]{2}{*}{ Diagnostic } & $\begin{array}{l}\text { Equal variances } \\
\text { assumed }\end{array}$ & 13.165 & .000 & .177 & 88 & .860 & .175 & .986 & -1.784 & 2.134 \\
\hline & $\begin{array}{l}\text { Equal variances not } \\
\text { assumed }\end{array}$ & & & .176 & 75.21 & .861 & .175 & .994 & -1.805 & 2.155 \\
\hline
\end{tabular}


Two groups were taught the same lessons for six weeks. Group A (Gold) was taught using Project-Based Learning in Understanding by Design framework while Group B (Garnet) was taught using a more traditional model of teaching focusing on lecturing and rote memory skills. Same formative tests were given on both groups however, formative assessments in Group A includes mentoring where students are open for questions regarding the points of the lessons where they find difficult. The teacher gives time for the students to clarify some concepts among themselves which helps them communicate well during the project making process. After the intervention, both groups took the second periodical exam. Independent samples $t$-test was used to determine whether or not the means of their scores are statistically significantly different. As seen in Table 7, there is a large difference on the mean scores of the two groups, Group A 35.89 while Group B 21.87. The independent samples $t$-test revealed that the mean scores of the two groups are statistically significantly different having a $p$ value of .000 less than .05 with 88 degrees of freedom.

Table 7. Second Periodical Test Mean Scores

\section{Group Statistics}

\begin{tabular}{ll|c|c|c|c} 
& Section & N & Mean & \multicolumn{1}{c}{$\begin{array}{c}\text { Std. } \\
\text { Deviation }\end{array}$} & \multicolumn{1}{c}{$\begin{array}{c}\text { Std. Error } \\
\text { Mean }\end{array}$} \\
\hline SecondPT & Gold & 44 & 35.89 & 5.919 & .892 \\
\cline { 2 - 7 } & Garnet & 46 & 21.87 & 4.167 & .614 \\
\hline
\end{tabular}

Table 8. Independent Sample T-Test of Second Periodical Test Results

\begin{tabular}{|c|c|c|c|c|c|c|c|c|c|c|}
\hline & & \multicolumn{2}{|c|}{$\begin{array}{l}\text { Levene's Test } \\
\text { for Equality of } \\
\text { Variances }\end{array}$} & \multicolumn{7}{|c|}{ t-test for Equality of Means } \\
\hline & & \multirow[b]{2}{*}{$\mathrm{F}$} & \multirow[b]{2}{*}{ Sig. } & \multirow[b]{2}{*}{$\mathrm{t}$} & \multirow[b]{2}{*}{ df } & \multirow{2}{*}{$\begin{array}{l}\text { Sig. (2- } \\
\text { tailed) }\end{array}$} & \multirow{2}{*}{$\begin{array}{c}\text { Mean } \\
\text { Difference }\end{array}$} & \multirow{2}{*}{$\begin{array}{l}\text { Std. Error } \\
\text { Difference }\end{array}$} & \multicolumn{2}{|c|}{$\begin{array}{l}95 \% \text { Confidence } \\
\text { Interval of the } \\
\text { Difference }\end{array}$} \\
\hline & & & & & & & & & Lower & Upper \\
\hline \multirow[t]{2}{*}{ SecondPT } & $\begin{array}{l}\text { Equal variances } \\
\text { assumed }\end{array}$ & 4.820 & .031 & 13.037 & 88 & .000 & 14.017 & 1.075 & 11.880 & 16.153 \\
\hline & $\begin{array}{l}\text { Equal variances } \\
\text { not assumed }\end{array}$ & & & 12.939 & 76.91 & .000 & 14.017 & 1.083 & 11.860 & 16.174 \\
\hline
\end{tabular}

\section{Motivation and Behavior}

The variety of my data collection methods helped me solidify my data analysis and answer the third research question. After the two units, I measured the students' motivation toward my science class using a survey questionnaire to be able to have a clearer picture of how my students felt about my subject, learning preferences, and school. I used Google Forms and Microsoft Excel in analyzing the survey data of the two groups. As seen in figures 4 and 5, responses of Group A are relatively pointing towards the positive side "agree" and "strongly agree" which indicate a higher motivation level of the group. Group B on the other hand shows more scattered responses.

Questions 2, 4, 9, and 15 were closely observed since they specifically focus on student motivation. Table 9 shows the percent of students of the two groups selecting a specific answer on the motivation questions. It is imperative to know the students' motivation towards science because it stimulates and maintains a positive attitude toward the subject (Andressa, 2015). The percentages exhibit that students on both groups want to come to school however, students in Group A are more motivated to work in my science class that can explain their higher achievement in the second periodical test. Overall, the motivation percentages of Group A are evidently higher than Group B (see Appendix D). In the open-ended part of the survey, most of the answers of Group A and Group B tell about their enjoyment during science activities. One of the students wrote; "The thing that I really like about science time is the activity part. I like doing projects with friends.". Some of them like science because they want to learn more things about their surroundings, a student wrote; "I love science class because I can now understand the things happening around me". On the other hand, most of the students in Group A dislike science class because of the amount of terminologies that they have to memorize and understand, whereas in Group B, they dislike science because they find lectures boring. Both groups came up with the same responses that agrees on students doing projects together. Most of their responses tell that in order for the project to be accomplished on time, they need to work together. They also argued that doing projects together not only lightens the workload but also the expenses their parents need to provide.

\section{Teacher Journal}

The teacher journal helped me in determining some students' behavioral patterns as well as the adaptation of the students who underwent the intervention. Using my notes, I was able to reflect on my own personal practice as a 
teacher and I was able to adjust my strategies based on the needs of the students. I maintained a journal a throughout the PBL-UbD experience. I recorded a cumulative observation and thoughts several times a week to avoid over-thinking or editing the journal. I recorded 15 handwritten pages of observations. As I read the data from my journal, I noticed drastic changes in behavior; from inattentive to attentive, from unattached to engaged, and from unconcerned to concern. The journey of Group A in adapting to a PBL classroom was never easy. Formative assessments and focus groups was the key in reinforcing PBL in Group A. Another overarching theme that came out was the use of technology. Since there were a lot or researches needed to come up with a good PBL project, students learned how to maximize the use of the internet. Sample pages from the original journal can be found in Appendix E.

\section{Interview}

After the Project-Based Learning Experience, I interviewed five students from Group A. The objective of the interview is to solicit information about what students felt about their projects, before, during, and after the process. The interview also added dimension to my data which helped me reinforce my data analysis. Considering that these students are just $6^{\text {th }}$ graders, I just made four simple interview questions:

1. How do you feel now about our science class?

2. What are the things that make science difficult for you?

3. Do you think science is important? Why?

4. What did you feel after accomplishing your project?

For the students to be able to express themselves well during the interview and to extract authentic responses, I let them answer in Filipino. I translated their responses as I jotted in the transcript. Here is an example of a response from one of the interviewees (see Figure 8).

The answers in questions 1, 2, 3 got quite identical responses. In question 4 two strands of answers came about. The first one is that they felt happy and accomplished because the project is finally over and they were able to follow the all the instructions given. Second is that they felt happy because the project was challenging and it was the first time they did such a meaningful project. It is evident that some students found the project meaningful and the sadness that they felt which is a negative emotion is actually a sign of a positive effect towards their attitude in handling responsibilities. In the unit on animals, the essential question was "Since we are living in an urban area, how can we make a self-sustaining source of food/ income using our knowledge in animals, plants and ecosystem?". The students came up with a poultry farm as a project proposal (see Appendix F). Using their knowledge in research they were able to integrate the lessons on plants wherein they used dried Malunggay leaves (Moringa Oleifera) as chicken feeds. They carefully and patiently worked on their project for four weeks and successfully attained their objectives. The reason why they felt sadness during the final stretch of the project is because of the fact that they had to let go of the chickens they took care for four months.

\section{Class Dojo}

Noting behavioral patterns of all the students would be difficult without the use of the internet application called Class Dojo. Going around the class of 40 plus students and noting each behavioral change whether it is positive or negative became easier. The teacher can also modify the positive and negative behavior icons based on his observation in the class and designate points that corresponds the behavior (see Figures 5 and 6). All throughout the PBL experience, I monitored and recorded the positive and negative attitudes the two groups exhibited (see Figure 8). The total number of positive points Group A received was 743 while only 488 for the Group B. One of the main reasons why Group B received less positive points than Group A is because Group A had more activities and hence, more chances to show positive behavior like "collaboration" and "helping others". The negative points accumulated by Group A was 57 compare with 98 in Group B.

Based on the data from the points in the Class Dojo, I believe that PBL did impact positive behavior in the classroom. At first, students in Group A only show positive attitudes to get the points, however, as they imbibe PBL during science class, doing positive attitudes such as being "on task", "participating" and "helping others" slowly becoming more natural. Darwin is a male student in Group A who happened to be a problem student. Absenteeism and tardiness are the two things that highly affect his academic achievement specially in science. Because of his absences he cannot keep up with the lessons that causes his mischievous behavior in class. Using the Class Dojo application, I was able to monitor the positive changes in his behavior all throughout the PBLUbD experience. In Figure 9, we can see that he has 24 positive points and a more comprehensive report of his points can be found on Table 11. His positive points increase while his negative points decrease as the PBL experience progress. Darwin enjoyed the activities that resulted several positive changes not only his attendance improved drastically, but also his class participation grew. I also discovered that he likes to draw that is why during group activities he is the one doing his group's illustrations. The supplementary information such as data collected and survey questionnaires are available upon request. 


\section{Conclusion}

On the basis of the findings on the diagnostic test and the second periodical test, it clearly shows that ProjectBased Learning using Understanding by Design as framework is a more effective teaching method for teaching science in the grade 6 level as reflected through the difference of the academic achievement scores between Group A (Gold) and Group B (Garnet). This action research revealed that students carrying out PBL activities had significantly higher achievement than those who continue a more traditional routine teaching in science classes. Project-Based Learning does not only increase academic achievement. Looking at the data coming from the survey, we can see that students who underwent PBL are more motivated to go to science classes and are able to see science subject as relevant. Students under PBL also perceive the importance of critical thinking and communication during group work. The data in the interview, teacher journal, and Class Dojo revealed that students enjoy collaborating with each other and learn more when engaged in authentic work.

\section{Recommendation}

Project-Based learning is a method that requires a lot of time from the teacher. To be able to craft a meaningful project the teacher has to make sure that the plan is student centered, came from a real-world problem, interdisciplinary, that will require collaboration, and should come up with an end product. Improving the academic achievement in science is no easy task, that is why teachers need to shift from a didactic to authentic type of teaching. Project-based learning method is suited with diverse learners. It enables the teachers to hone not only the skill in science that the students need to acquire, but more importantly, the $21^{\text {st }}$ century skills such as critical thinking, collaborating, creativity, computer literacy, and cross cultural understanding. Teacher preparedness in doing a "grassroots" method of teaching such as PBL is an integral part of the success in implementing such an innovative learning program. Incorporating the study of PBL in the undergraduate programs for our future educators will be a great start. The study proved the effectiveness of PBL in increasing the academic achievement in Science. Further investigation is needed to see the potential of PBL in other subject areas.

\section{REFERENCES}

Almasaeid, T. (2017). The impact of using understanding by design (UbD) on $8^{\text {th }}$ grade students' achievement in $\begin{array}{lllll}\text { science. } & \text { European } & \text { Scientific } & \text { Journal. } & \text { Vol }\end{array}$ 30315https://eujournal.org/index.php/esj/article/view/8853

Altun Yalcin, S., Turgut, U., \& Buyukkasap, E., (2009), The effect of project-based learning on science undegraduates' learning of electricity, attitude towards physics and scientific process skills, International $\begin{array}{lllll}\text { Online Journal of } & \text { Educational }\end{array}$ http://journaldatabase.info/download/pdf/effect_project_based_learning_on

Andressa, H., Mavrikaki, E., \& Dermitzaki, I. (2015), Adapatation of the students' motivation towards science learning questionnaire to measure students motivation towards biology learning. International Journal of Biology Education. Vol. $\quad 4, \quad$ Issue $42, ~ 78-93$, http://dergipark.ulakbim.gov.tr/ijobed/article/download/5000163650/5000147650,http://dergipark.ulakbim. gov.tr/ijobed/article/view/5000163650/50001476

Anwaruddin, S. (2013). Understanding by design: EFL teachers' perception. Asian EFL Journal Press. retrieved from http:/www.asian-efl-journal.com

Barron, B. \& Darling-Hammond (2008), Teaching for meaningful learning: A review of research on inquirybased and cooperative learning, 2-15, retrieved from https:/www.edutopia.org/pdfs/edutopia-teaching-formeaningfullearning.pdf

Bartscher, K., Gould, B., Nutter, S., (1995), Increasing student motivation through project-based learning, Saint Xavier University \& IRI Skylight, https://eric.ed.gov/?id=ED392549

Bell, S., (2010). Project-based learning for the $21^{\text {st }}$ century: Skills for the future. The Clearing House, 83: 39 43https://eric.ed.gov/?id=EJ872047

Cakici, Y., Turkmen, N., (2013), An investigation of the effect of project-based learning approach on children's' achievement and attitude in science, The Online Journal of Science and Technology, Vol.3, Issue 2, 9-17 https://www.tojsat.net/journals/tojsat/articles/v03i02/v03i02-02.pdf

Cervantes, B., Hemmer, L., \& Kauzekanani, K., (2015), The impact of project-based learning on minority student achievement: Implication fro school redesign, National Council of Professors of Educational Administration, Vol. 2, (2) https://files.eric.ed.gov/fulltext/EJ1105713.pdf

Chiang, C. L., Lee, H., (2016), The effect of project-based learning on learning motivation and problem-solving ability of vocational high school students, International Journal of Information and Educational Technology, Vol. 6, No. 9, 709-712, DOI:10.7763/IJIET.2016.V6.779

Condliffe, B. (2016), Project-based learning: A literature review, Lucas Education Research, retrieved from https://s3-us-west 1.amazonaws.com/ler/MDRC+PBL+Literature+Review.pdf 
Dewey, J. (1938), Experience and education, Kappa Delta Pi, USA, https://archive.org/details/ExperienceAndEducation

Educational Technology Division, (2006), Ministry of Education Communications and Training Sector Smart Pesiaran Bukit Kiara 50604 Kuala Lumpur Malaysia, retrieved from: https://sekolah21.files.wordpress.com/2010/05/project-based-learning-handbook.pdf

Erdem, E., (2012), Examination of the effects of project-based learning approach on students' attitudes towards chemistry and test anxiety, World Applied Sciences Journal, IDOSI Publications, 17 (6), 764-769, https://www.idosi.org/wasj/wasj17(6)12/15.pdf

Ergul, R. N., \& Kargin, E. K., (2013), The effect of project-based learning on students' science success, Procedia Social and Behavioral Sciences, 136, 537-541, doi:10.1016/j.sbspro.2014.05.371

Grant, M. M., (2002), Getting a grip on project-based learning: Theory, cases and recommendations, Meridian, A Middle School Computer Technologies Journal, Vol. 5,Issue 1, http://www.ncsu.edu/meridian/win2002/514/3.html

Halvorsen, A., Duke, N. k., Brugar, K., Block, M., Strachan, S., Berka, M., \& Brown, J., (2014), Narrowing the achievement gap in second-grade social studies and content are literacy: The promise of a project-based approach, Education Policy center, Michigan State University, 3-27

Harmer, N. \& Strokes, A. (2014), The benefits and challenges of project-based learning: A review of the literature, Pedagogical Research Institute and Observatory (PedRIO), Plymouth University, 10-30, https://www1.plymouth.ac.uk/research/pedrio/Documents/PedRIO\%20Paper\%206.pdf

Hodaeian, M. \& Biria, R. (2015). The effect of backward design on intermediate EFL learners' L2 reading comprehension: Focusing on learners' attitudes. Journal of Applied Linguistics and Language Research. Vol. 2. (7). 80-93 www.jallr.ir

Holmes, L., (2012), The effects of project-based learning on $21^{\text {st }}$ skills no child left behind http://ufdc.ufl.edu/UFE0044088/00001

Holubova, R. (2008), Effective teaching methods: Project-based learning in physics, Faculty of Science, Palacy University Olomouc Svobody, Czech Republic, Vol. 5, No. 49, http://files.eric.ed.gov/fulltext/ED504949.pdf

Iwamoto, I., Hargis, J., \& Voung, K. (2016) : The effect of project-based learning on student performance: An action research study, International Journal for the Scholarship of Technology enhanced Learning, Vol. 2,(1), 24-42 http://ejournals.library.gatech.edu/ijsotel/index.php/ijsotel/article/view/5

Katz, L. G., \& Chard, S. C. (1992). The project approach, retrieved from: https://archive.org/stream/ERIC_ED340518/ERIC_ED340518_djvu.txt

Keller, E. (2012) Kids are natural-born scientists, retrieved from: https://www.kidsdiscover.com/teacherresources/natural-born-scientists/

Khaliq, S., Alam, M. T., \& Mushtaq, M., (2015). An experimental study to investigate the effectiveness of project-based learning (PBL) for teaching science at elementary level, International Journal of Academic Research in Progressive Education and Development, Vol. 4, 43-55, Issue 1, DOI:10.6007/IJARPED/v4i1/1434 URL: http://dx.doi.org/10.6007/IJARPED/v4-i1/1434

Larmer, J., \& Mergendoller, J. R. (2015). Why we changed our model of the "8 essential elements of PBL." Buck Institute for Education. Retrieved from www.bie.org.

Mayer, K. (2016). Students' perceptions of the life skill development in project-based learning schools, Journal of Educational Issues, Vol. 1, (1) doi:10.5296/jei.v2i1.8933

Martin, D. J. (2002) Elementary science methods: A constructivist approach, (3 ${ }^{\text {rd }}$ ed.), Wadsworth Publishing Company, 14-50

Matthews, W. J. (2003), Constructivism in the classroom: Epistemology, history, and empirical evidence, Teacher Education Quarterly, 51-64, retrieved from: https://eric.ed.gov/?id=EJ852364

Mullis, I., Martin, M. O., Gonzales, E. J., \& Chrostowski, S. J., (2004), TIMSS 2003 International Mathematics Report, International Association for the Evaluation of Educational Achievement, Boston College, https://timss.bc.edu/PDF/t03_download/T03INTLMATRPT.pdf

Ravitz, J., Hixson, N., English, M., \& Mergendoller, J. (2012). Using project based learning to teach $21^{\text {st }}$ century skills: Findings from a statewide initiative, 1-9.

Ramos, P. H., De La Paz, S., (2009), Learning history in middle school by designing multimedia in a projectbased learning experience, Journal of Research on Technology in Education, International Society for Technology in Education, 151-173, https://www.researchgate.net/publication/271672153_Learning_History_in_MiddleSchool_by Designing_Multimedia_in_a_Project Based_Learning_Experience

Redmond, K. (2014), The effect of project-based learning on student achievement in a fourth grade classroom, Montana University, Bozeman

https://scholarworks.montana.edu/xmlui/bitstream/1/3587/1/RedmondK0814

Montana 
Roth, W. M. ( 1990), Collaboration and constructivism in the science classroom, Annual convention of the American Research Association, Boston, https://eric.ed.gov/?id=ED318631

Schiller A. (2015). Understanding by design unit lesson plans for the next generation science standards: Life science. Graduate Research Papers. 73. http://scholarwork.uni.edu/grp/73

Sgro, S. \& Freeman, S. (2008). Teaching critical thinking using understanding by design. Agricultural and Biological Engineering Proceedings anference Presentations http://lib.dr.iastate.edu/abe_eng_conf/224/

Tam, M. (2000), Constructivism, instructional design, and technology: Implications for transforming distance learning, Educational Technology and Society, 3(2),50-60, mtam@ln.edu.hk

Thomas, J. W. (2000), A review of research on project-based learning, The Autodesk Foundation, California, http://www.bie.org/index.php/site/RE/pbl_research/29

Tumlos-Castillo, L. (2015). Initial evaluation of the understanding by design (UbD) framework in writing learning modules. $\quad \mathrm{De} \quad \mathrm{La} \quad$ Salle University. retrieved from:http://www.dlsu.edu.ph/conferences/dlsu_research_congress/2015/1li/LLI-I-004.pdf

Tyler, R. (1949), Basic principles of curriculum instruction, $\bar{C}$ hicago Press, 30-45

UNESCO, (2010), Current challenges in basic science education, Education Sector http://unesdoc.unesco.org/images/0019/001914/191425e.pdf

Vega, V. (2015), Project-based learning research review, retrieved from https://www.edutopia.org/pbl-researchlearning-outcomes

Vygotsky, L. (1978). Interaction between learning and development. In Gauvin 7 Cole (Eds) Readings on the Development of Children. New York, 34-40 http://www.psy.cmu.edu/ siegler/vygotsky78.pdf

Wiggins, G., \& McTighe, J. (2005). Understanding by design ( $2^{\text {nd }}$ ed.) Alexandria, VA: ASCD

Wiggins, G., \& McTighe, J. (2011). Understanding by design: Creating quality units. Alexandria, VA: ASCD

Wolf, K., \& Stevens, E. (2007). The role of rubrics in advancing and assessing student learning. The Journal of Effective Teaching and Online Journal Devoted to Teaching Excellence. Vol. 7, (1), 3-14 https://files.eric.ed.gov/fulltext/EJ1055646.pdf

Yurtseven, N. \& Altun, S., (2015). Understanding by design (UbD) in EFL teaching: The investigation of students' foreign language learning motivation and views. Journal of Education and Training Studies, Vol. 4. (3). 51 http://dx.doi.org/10.11114/jets.v4i3.1204 